DOI 10.37882/2223-2982.2021.01.05

\title{
ЛЕКСЕМА-СОМАТИЗМ ПӐЛ ‘УХО’ ВО ФРАЗЕОЛОГИЗМАХ ШУРЫШКАРСКОГО ДИАЛЕКТА ХАНТЫЙСКОГО ЯЗЫКА
}

\section{TOKEN-SOMATISM P'EAR' \\ IN THE PHRASEOLOGICAL UNITS \\ OF THE SHURYSHKAR DIALECT \\ OF THE KHANTY LANGUAGE}

\section{Vozelova}

Summary: Based on the material of the shuryshkar dialect of the Khanty language, somatic phraseological units represent a large group. The article presents a semantic analysis of phraseological units with the somatic component NLL 'ear' in the Khanty language. The results of semantic analysis presented by us are not only of practical and theoretical significance, but can also be applied in the creation of bilingual dictionaries, as well as in their distribution in the Khanty language and their use in speech.

Keywords: phraseological unit, lexeme, somatism, ear, Khanty language, shuryshkar dialect.
$\Phi$ разеологические единицы разных языков мира являются предметом многочисленных исследований.

Фразеологические единицы разных языков мира являются предметом многочисленных исследований.

Для начала определимся с понятием: «соматические» фразеологические единицы - это такие ФЕ, где один из компонентов выражен словом - названием какой-нибудь части человеческого тела, например: самdl шовэр хорпи 'трусливый (букв.: сердце=его как у зайца); воllы йошкфр сохыы питmы 'обессилеть (букв.: без рук-ног стать)'; охен ӑтма йис 'с ума сойти (букв.: голова=твоя плохой стала)'; кфрydldl păma ворdmмdн омdcdl 'бездельничает (букв.: ноги=свои уперев в очаг, сидит)' и т.д.

Как известно «сома» с греческого языка переводится как «тело».

В данной статье мы попытаемся проанализировать компонент - соматизм пӑл'ухо'в контексте его использования в хантыйских фразеологизмах.

Исследование фразеологии любого языка невозможны без теоретико-методологической базы и это связано с такими выдающимися учёные как А.М. Бабкин, В.В.Виноградов, В.П.Жуков, А.В.Калинин, А.М.Мелерович, В.М. Мокиенко, А.И. Молотков, В.М. Огольцов, В.Н. Телия,
Возелова Любовь Геннадьевна

М.н.С., Государственное казенное учреждение Ямало-Ненецкого автономного округа «Научный центр изучения Арктики», г. Салехард Ivozelova@mail.ru

Аннотация: На материале шурышкарского диалекта хантыйского языка соматические фразеологизмы представляют большую группу. В статье представлен семантический анализ фразеологических единиц с соматическим компонентом пӑl 'ухо' в хантыйском языке. Представленные нами результаты семантического анализа имеют не только практическое и теоретическое значение, но и могут быть применены в создании двуязычных словарей, а также в их распространении в хантыйском языке и их использование в речи.

Ключевые слова: фразеологическая единица, лексема, соматизм, ухо, хантыйский язык, шурышкарский диалект.

\section{Н.М. Шанский и др.}

Без трудов ученых финно-угроведов таких как, В.М. Вахрушева, О.А. Гагариной (Поповой), Ф.Т. Грачевой, А.Н. Кармановой, И. Козмача, Г.О. Надя, Д. Пацолаи, И.И. Тарабукина, 3. Уйвари, В.П. Федотовой, Л. Хадровича, Р.С. Ширманкиной, Э. Якимовой и др. не представляется возможным провести полноценные исследования по родственным языкам, в частности по хантыйскому языку.

Соматические фразеологизмы (от. греч. soma - тело), содержащие в лексико-синтаксической структуре компоненты, номинирующие части тела человека, заслуживают отдельного внимания.

Слово «соматический» применяется в биологии, медицине и имеет следующий смысл «связанный с телом человека, телесный» и противопоставляется понятию психический».

Известно, что впервые в финно-угроведении термин «соматический» ввёл Ф. Вакк. [1. Вакк Ф.О. О соматической фразеологии в современном эстонском литературном языке: автореф. дис. ... канд. филол. наук. - Таллинн, 1964. - 29 с.]. Исследуя фразеологизмы эстонского языка, в составе в которых имеются слова, называющие части человеческого тела, их назвал соматическими. Также он пришел к выводу о том, что они являются одним из древнейших слоев фразеологии и составляют наибо- 
лее употребительную часть фразеологического состава эстонского языка. И так, со второй половины XX в. термин «соматический» начал активно применяться в исследованиях слов, отражающих в семантике всё, что относится к сфере телесности.

Анализируя и классифицируя собранный нами материал по «Фразеологии хантыйского языка» (на материале шурышкарского диалекта) мы пришли к выводу, что самым распространенными компонентами во фразеологии являются названия наружных частей человеческого тела, функционально очевидных для человека, - соматизмы: јх «голова», йош 'рука', кфр 'нога', сэм 'глаз' , венш' лицо' , njl 'нос', năl 'ухо' и др.

К выше сказанному, в статье «Слова обозначающие части тела человека, на примере фразеологизмов хантыйского языка (на материале шурышкарского диалекта), где автор, пишет о том, что «наиболее частотными соматическими компонентами по фразеологической активности в составе хантыйского языка являются такие лексемы, как как сӑм 'сердце' 37, 2 \%, йјш 'рука' 19,4 \%, jх 'голова $15 \%$, кфр 'нога 13,3 \%), венш 'лицо' 7,8 \%, пӑl 'ухо' 4,4 \%, пенк 'зуб' 2,8 \%.( Л.Г. Возелова, Слова, обозначающие части тела человека, на примере фразеологизмов хантыйского языка (на материале шурышкарского диалекта)), стр. 53, Научный вестник ЯНАО № 3 (92). Обдория: — № 3 (92). — Н 34 Тюмень, 2016. — 136 с.)

Следует отметить, что приведенные выше статистические подсчеты могут измениться, так как хантыйский язык характеризуется большой диалектной раздробленностью, а диалекты в свою очередь подразделяются на множество говоров. Автор проанализировал лишь небольшое количество фразеологических единиц хантыйского языка на материале именно шурышкарского диалекта.

Представленная работа, посвященная семантическому анализу соматизма пӑл 'ухо' во фразеологической системе хантыйского, отвечает вызовам времени и потому является актуальной.

По фразеологии хантыйского языка опубликованы статьи на материалах казымского, приуральского и шурышкарского диалектов следующих авторов: В.Н. Соловар, А.Д. Каксина, З.С. Рябчиковой, А.И. Кузнецовой, М.Е. Серасховой, Ю.Г. Миляховой, А.А. Сязи. [Динисламова О.Ю. Антропоцентризм языка и его отражение во фразеологии мансийского и русского языков (на примере фразеологизмов с оценкой интеллектуальных качеств человека) // Вестник угроведения. 2018. №2.)

Помимо вышеперечисленных работ, также изданы статьи по фразеологии мансийского языка, авторами которых являются Л.Н. Панченкои, О.Ю. Динисламовой. (Соловар Валентина Николаевна, Семантика фразео- логизмов-соматизмов с компонентом сым/сӑм 'сердце' в обско-угорских языках // Финно-угорский мир. 2017. №4 (33). URL: https://cyberleninka.ru/article/n/semantikafrazeologizmov-somatizmov-s-komponentom-sym-cm-serdtse-v-obsko-ugorskih-yazykah (дата обращения: 25.11.2020).

Фразеологическая система каждого языка обладает национальными особенностями. В системе фразеологии хантыйского языка значительное место занимают соматические фразеологизмы.

Материалом для данного исследования послужили хантыйские фразеологизмы с компонентом-соматизмом пӑl'yхо', выделенные нами методом сплошной выборки из монографии «Парные слова хантыйского языка (на материале шурышкарского диалекта) А.А. Шияновой, из атласа «Диалектологический атлас уральских языков, распространенных на территории Ямало-Ненецкого автономного округа» Н.Б. Кошкарева [и др.], а также из «Словарь образных слов и выражений хантыйского языка» Рябчикова 3.С., Рачинская М.А.

В перечисленных изданиях многие фразеологические единицы с компонентом пӑл «ухо» хантыйского языка шурышкарского диалекта совпадают.

Целью данной работы является семантический анализ фразеологизмов с компонентом пал «ухо» в хантыйском языке на материале шурышкарского диалекта.

Все звуки, что мы слышим проходят через наши уши, и от состояния слуха во многом зависит полноценность восприятия окружающего мира.

По определению Ожегова С.И. и Шведова Н.Ю. «Ухо орган слуха, а также наружная часть его (у человека - в форме раковины). Внутреннее, среднее, наружное. [7, с. 844]. 7. Ожегов С.И., Шведова Н.Ю. Толковый словарь русского языка. М.: Азбуковник, 1990. 939 с.

В хантыйском языке лексема năl с помощью существительного Іеккар образует словосочетание и обозначает профессию năl lеккар (букв.: врач ушей) отоларинголог.

Фразеологизмы хантыйского языка шурышкарского диалекта с компонентом пӑl ' ухо' нами были распределены по следующим семантическим группам.

1. Фразеологические единицы (ФЕ) со значением «слушать невнимательно, не реагировать»: năl uфndн хулантәл 'невнимательный (букв.: половиной уха слушает)'; nălldl ljn метшӑсlы ' невнимательный (букв.: уши свои заткнул)';а муй пӑl ӑнт тайӑl 'глухой (букв.: разве ушей не имеет) или том, кто не реагирует на обращенную к нему речь за глухоты или притворяется, что не слышит '; пӑllы 
верасdc'не слушать собеседника ( букв.: как будто без ушей); пӑл пеІакна хфлантәл'невнимательный (букв.: в пол ухо слушает)'.

2. ФE со значением «плохо слышать»: Пӑlldл кеla йucdm'туг на ухо (букв.:Уши= его стали толстыми)'; Пӑлләм воллы ло̆п мӑнтсәт 'туг на ухо (букв.:Уши =его совсем закрылись).

3. ФЕ со значением «не давать покоя»: Ӑ фва пӑл вфudн 'надоедать (букв.: не кричи над ухом)'.

4. Фразеологические единицы (ФЕ) со значением «потерять слух частично или полностью»: Пӑllbl numcdм '(букв.: без ушей стал)'; Пӑllы хӑщсdм '(букв. Остался без ушей) '; Пӑl ăнm maйăl '(букв. Ушей = у него нет)'; Пăldl вjllы ăнm xфllam 'глухой ( букв.:Уши=его совсем не слышат)'; Пӑlэм ӑн хфlal 'глухой(букв.: Ухо=его не слышит)'.

5. Фразеологические единицы (ФЕ) со значением «глухой»: Пӑллы шфn 'глухой (букв.: без ушей)'; Паллы om ' глухой ( букв.: Без уха)'; ПӑІ луфк 'глухой (букв.: уши глухаря)'; Сэмды-пӑllы 'слепой-глухой (букв.: Без глаза - без уха)'; Пӑllы- сэм/ы ' глухойслепой (букв.: без уха- без глаза)'; Пӑl ăнm maŭdl 'глухой (букв.:Он ушей не имеет)'.

6. Фразеологические единицы (ФЕ) со значением «звенит, шумит»: Пӑl вфсэм xălaйdн фвla 'звенит в ухе (букв.: В отверстие уха моего покойник кричит)' и по приметам народа ханты в таких случаях всегда говорить: Потdм вјŭ пфlэм ӑнma хоldl, aнm ŭuldм (бук.: холодный кусок масла не кончился, не приду)'.

7. Фразеологические единицы (ФЕ) со значением «иметь хороший слух»: Сэмат-пӑатт ' острый слух (букв. с глазами-ушами) '.

8. Фразеологические единицы (ФЕ) со значением «потерять»: Njllbl -năllы ' Впустую (Букв.:без нюха, без слуха)'.

Таким образом, нами проанализировано 22 ФЕ с компонентом пӑl 'ухо', также распределены по восьми семантическим группам: «слушать невнимательно, не реагировать», «плохо слышать», «не давать покоя», «потерять слух частично или полностью», «глухой», «звенит, шумит», «иметь хороший слух» «потерять».

Проведенное нами исследование выявило, что лексема пӑl 'ухо' не является распространённым элементом в образовании фразеологизмов.

Подводя итог, мы пришли к выводу, что предстоит всесторонне изучить фразеологический фонд хантыйского языка, хантыйские говоры Ямало-Ненецкого автономного округа, исследовать степень устойчивости фразеологических единиц, структуру фразеологизмов, их семантику и классификацию. Фразеологизмы хантыйского языка делают нашу речь стилистически окрашенной и образной.

\section{ЛИТЕРАТУРА}

1. Вакк Ф.О. 0 соматической фразеологии в современном эстонском литературном языке: автореф. дис. ... канд. филол. наук. - Таллинн, 1964. - 29 с.

2. Л.Г. Возелова, Слова, обозначающие части тела человека, на примере фразеологизмов хантыйского языка (на материале шурышкарского диалекта) // Научный вестник ЯНАО № 3 (92). Обдория: — № 3 (92). — Н 34 Тюмень, 2016. — 136 с.

3. Попов А.А. Пережитки древних дорелигиозных воззрений долганов на природу // Советская этнография. 1958. № 2.С. 37-45].

4. Шанский Н.М. Фразеология современного русского языка. М.: Высшая школа, 1985. 160 с).

5. Егоров А.В. Удмуртская соматическая фразеология (в сопоставлении с венгерской). Екатеринбург-Ижевск: Ур0 РАН, 2011 - 18 с

6. Динисламова 0.Ю. Антропоцентризм языка и его отражение во фразеологии мансийского и русского языков (на примере фразеологизмов с оценкой интеллектуальных качеств человека) // Вестник угроведения. 2018. №2.

7. Соловар Валентина Николаевна Семантика фразеологизмов-соматизмов с компонентом сым/сӑм'сердце' в обско-угорских языках // Финно-угорский мир. 2017. №4 (33).

8. Шиянова А.А. Парные слова хантыйского языка (на материале шурышкарского диалекта): монография. - Тюмень: 000 «ОРМАТ», 2015.156 с.

9. В.Н. Соловар Хантыйско-русский словарь (казымский диалект) - Тюмень: 000 «ФОРМАТ», 2014. - 386 с.

10. Диалектологический атлас уральских языков, распространенных на территории Ямало-Ненецкого автономного округа / Н.Б. Кошкарева [и др.] / Под ред. Н.Б. Кошкаревой. - Калининград: Издательский Дом «РОСТ-ДОАФК», 2017. - 256 с.

11. Рябчикова 3.С., Рачинская М.А. Словарь образных слов и выражений хантыйского языка. - СПБ.: Алмаз-Граф, 2015. - 80 с.

( ) Возелова Любовь Геннадьевна (Ivozelova@mail.ru).

Журнал «Современная наука: актуальные проблемы теории и практики» 